\title{
Cellular distribution and ontogeny of insulin-like growth factors (IGFs) and IGF binding protein messenger RNAs and peptides in developing rat pancreas
}

\author{
D J Hill 1,2,3,4 J Hogg $^{1,2}$, J Petrik ${ }^{1,2,4}$, E Arany ${ }^{1,3}$ and \\ V K M Han ${ }^{1,4,5,6}$
}

'Lawson Research Institute, St Joseph's Health Centre, London, Ontario, Canada N6A 4V2

${ }^{2}$ Department of Physiology, University of Western Ontario, London, Ontario, Canada N6A 5A5

${ }^{3}$ Department of Medicine, University of Western Ontario, London, Ontario, Canada N6A 5A5

${ }^{4}$ Department of Paediatrics, University of Western Ontario, London, Ontario, Canada N6A 5A5

${ }^{5}$ Department of Anatomy and Cell Biology, University of Western Ontario, London, Ontario, Canada N6A 5A5

${ }^{6}$ Department of Obstetrics and Gynaecology, University of Western Ontario, London, Ontario, Canada N6A 5A5

(Requests for offprints should be addressed to D J Hill, Lawson Research Institute, St Joseph's Health Centre, 268 Grosvenor Street, London, Ontario,

Canada N6A 4V2)

\begin{abstract}
To determine the role of insulin-like growth factors (IGFs) and their binding proteins (IGFBPs) in the development of the pancreas, and specifically of the islets of Langerhans, we have examined the cellular distribution and developmental changes in the expression of IGFs and IGFBPs in the pancreas of the fetal and neonatal rat between 19.5 days of gestation and postnatal day 28. This represents a period of substantial growth and restructuring of the $\beta$ cell component in islets of this species. IGF-I, IGF-II, and IGFBPs-1 to -6 mRNAs were localized by in situ hybridization, and peptides by immunohistochemistry, in histological sections. IGF-II mRNA was highly expressed in islet cells and some ductal epithelial cells in late fetal and early neonatal life, but was barely detectable by postnatal day 28. IGF-II peptide showed a similar distribution. IGF-I mRNA was barely detected in the fetus or neonate and was localized predominantly in the ductal and acinar tissues after postnatal day 7. IGF-I immunoreactivity was associated with some islet cells in the fetus and neonate, suggesting an endocrine rather than a paracrine source.
\end{abstract}

We performed co-localization studies to assess whether the distribution of IGFs within the pancreas might be due to a sequestration by locally produced IGFBPs. The presence of mRNAs for both IGFBPs-1 and -2 was minimal in the pancreas prior to postnatal day 7 , although subsequently IGFBP-1 mRNA was seen in islet cells, while IGFBP-2 mRNA was localized in both islets and acinar tissues. In contrast, both IGFBPs-1 and -2 immunoreactivities were identified in islets from late fetal life, suggesting a circulatory source for these IGFBPs during early pancreatic development. IGFBPs-3 to -5 mRNAs and immunoreactivities were identified within islet cells throughout fetal and neonatal life, with IGFBPs- 3 and -5 being mainly associated with the $\alpha$ cell-rich islet mantle. The results show a compartmentalization of IGFs within pancreatic tissue, reflecting both paracrine and endocrine sources. The localization and action of IGFs in pancreas likely involves sequestration and distribution by endogenous as well as circulating IGFBPs.

Journal of Endocrinology (1999) 160, 305-317

\section{Introduction}

The ability to increase $\beta$ cell mass in the pancreatic islets of Langerhans by cell proliferation of existing $\beta$ cells, as well as islet neogenesis (differentiation of new $\beta$ cells), is essential for the increasing insulin requirements of the growing fetus and neonate (Finegood et al. 1995). Substantial evidence supports a role for insulin-like growth factors (IGFs) in islet cell replication and function. We and others have shown that human or rat fetal and neonatal islets release IGF-I and IGF-II (Rabinovitch et al. 1982, Romanus et al. 1985, Hill et al. 1987, Swenne et al. 1987,
Scharfmann et al. 1989, Hogg et al. 1993), while exogenous IGFs-I or -II promote increased islet cell DNA synthesis (Rabinovitch et al. 1982, Swenne et al. 1987, Hogg et al. 1993). Isolated rat islet $\alpha$ and $\beta$ cells express the high affinity IGF type 1 signalling receptor (Van Schravendijk et al. 1987), which is also present in isletderived cell lines synthesizing insulin, glucagon or somatostatin (Fehmann et al. 1996). IGF-I inhibits insulin release by adult islet $\beta$ cells in vitro and in vivo (Guler et al. 1989, Van Schravendijk et al. 1990). However, perifusion of adult islets with IGFs-I or -II causes biphasic effects on glucose-stimulated insulin release (Hill et al. 1997). We 
previously reported, based on Northern blot hybridization, that the major IGF expressed within whole pancreas in the fetal and neonatal rat was IGF-II, but that expression declined two weeks following birth, to be replaced by IGF-I expression (Hogg et al. 1994). This developmentally regulated alteration in IGF expression is seen in many other tissues, and is reflected in the circulating peptides, although the timing of a change from IGF-II to IGF-I expression differs between tissues (Brown et al. 1986).

The IGFs are usually found associated with up to six high affinity binding proteins (IGFBPs-1 to -6) in tissues and biological fluids. In addition to extending the biological half-life of IGFs in blood and extravascular fluids, the IGFBPs also modulate the biological actions of IGFs on isolated cells and tissues (McCusker \& Clemmons 1992). Using isolated fetal rat islets, we demonstrated a release of IGFBPs-1 to -4 , with IGFBPs-1 and -2 release being upregulated by glucose or amino acids (Hogg et al. 1993). Exogenous IGFBPs-1 or -2 were able to potentiate the mitogenic actions of IGF-II on fetal islets. Similarly, in the mid-trimester human fetus, IGF peptides and IGFBPs-1, -2 and -3 are localized to islets, including $\beta$ cells (Hill \& Clemmons 1992). When we examined the ontogeny of IGFBP mRNA expression in the whole rat pancreas using Northern blotting, IGFBP-1 mRNA was undetectable and IGFBP-2 mRNA was very low in the fetal and neonatal pancreas, but both IGFBP mRNAs transiently appeared between 2-3 weeks of age and then declined in the adult. IGFBPs- 3 and -4 mRNAs are expressed in the pancreas throughout development (Hogg et al. 1994).

These analyses, however, do not reveal cellular compartmentalization of IGFs or IGFBPs within the developing pancreas. Pancreatic $\beta$ cell mass progresses in early life by a combination of islet cell neogenesis and the proliferation of existing islet cells, balanced by developmentally regulated $\beta$ cell apoptosis (Scaglia et al. 1997). It is therefore important to determine whether IGFs and their binding protein mRNAs are expressed, and the proteins localized, to islet cells or adjacent acinar or ductal epithelial cell populations in order to postulate their likely contribution to islet neogenesis, hyperplasia, or both. The present studies report a distinct anatomical and developmental pattern of expression and peptide localization of IGF-I, IGF-II and IGFBPs in the fetal and neonatal rat pancreas.

\section{Materials and Methods}

\section{Animals}

Pregnant Wistar rats (Charles River, Montreal, PQ, Canada) were killed at days 19.5 or 21.5 of gestation, or were allowed to deliver and the offspring killed between postnatal days 2 and 28. Rat fetuses were decapitated with scissors, while the pregnant females and all rats at postnatal ages were killed by $\mathrm{CO}_{2}$ asphyxiation. Pregnant and suckling rats were allowed free access to food and water. All procedures were performed with ethical approval of the Animal Care Committee of the University of Western Ontario. Pancreata were dissected quickly and fixed in ice-cold fixative (4\% paraformaldehyde and $0 \cdot 2 \%$ glutaraldehyde buffered with $70 \mathrm{mM}$ phosphate buffer, $\mathrm{pH} 7 \cdot 4$ ) for $16 \mathrm{~h}$ at $4{ }^{\circ} \mathrm{C}$, followed by four washes at $4{ }^{\circ} \mathrm{C}$ in phosphate-buffered saline (PBS) over a 48 -h period. Fixed tissues were dehydrated in $70 \%(\mathrm{v} / \mathrm{v})$ ethanol and embedded in paraffin.

\section{Immunohistochemistry}

Histological sections of pancreas $(5 \mu \mathrm{m})$ were prepared and mounted on glass microscope slides (Superfrost Plus, Fischer Scientific, Nepeon, ON, Canada). Immunohistochemistry was performed to localize IGFs-I or -II, or IGFBPs using a modified avidin-biotin peroxidase method (Hsu et al. 1981) as described by us previously (Petrik et al. 1998). Slides were incubated for $48 \mathrm{~h}$ with either rabbit anti-human IGF-I or IGF-II (1:2000 dilution) (GroPep Ltd, Adelaide, Australia), rabbit anti-human IGFBPs-1, $-2,-3,-4$ and -5 (all at 1:1000 dilution), or monoclonal antibody against human IGFBP-6 (1:500 dilution) (Austral Biologicals, San Ramon, CA, USA). Biotinylated goat anti-rabbit immunoglobulin $G(\operatorname{Ig} G)(1: 500)$, or goat anti-mouse $\operatorname{IgG}(1: 100)$ (Vector Laboratories, Burlingame, CA, USA) were used as second antibodies and diaminobenzidine tetrahydrochloride (DBS tablets, $10 \mathrm{mg}$, Sigma Chemical Co., St Louis, MO, USA) was used as the chromagen. Tissue sections were counter-stained with Carazzi's haematoxylin. To establish specificity of staining, the primary antisera to IGFs-I or -II were pre-absorbed overnight at $4{ }^{\circ} \mathrm{C}$ with $100 \mathrm{nM}$ homologous ligand prior to application to the sections. Antisera against IGFBPs were pre-absorbed with $100 \mathrm{nM}$ homologous or heterologous IGFBP proteins (Austral). All antisera were found to be specific as stated by the supplier, with the exception of antiserum against IGFBP-4, which showed crossreactivity with IGFBP-2. Further controls included substitution of primary antisera with non-immune serum and omission of the secondary antiserum.

\section{In situ hybridization}

In situ hybridization for IGFs-I, -II and IGFBPs-1 to -6 was performed on histological paraffin sections of pancreas as described previously (Petrik et al. 1998). Sections were counter-stained with haematoxylin and eosin, and were viewed under dark and bright field microscopy. As controls for non-specific hybridization, hybridization was also carried out (i) using sense probes, and (ii) using antisense probes on sections previously incubated with ribonuclease A (RNase A) to degrade the RNA. Where comparisons were made between pancreata from animals 

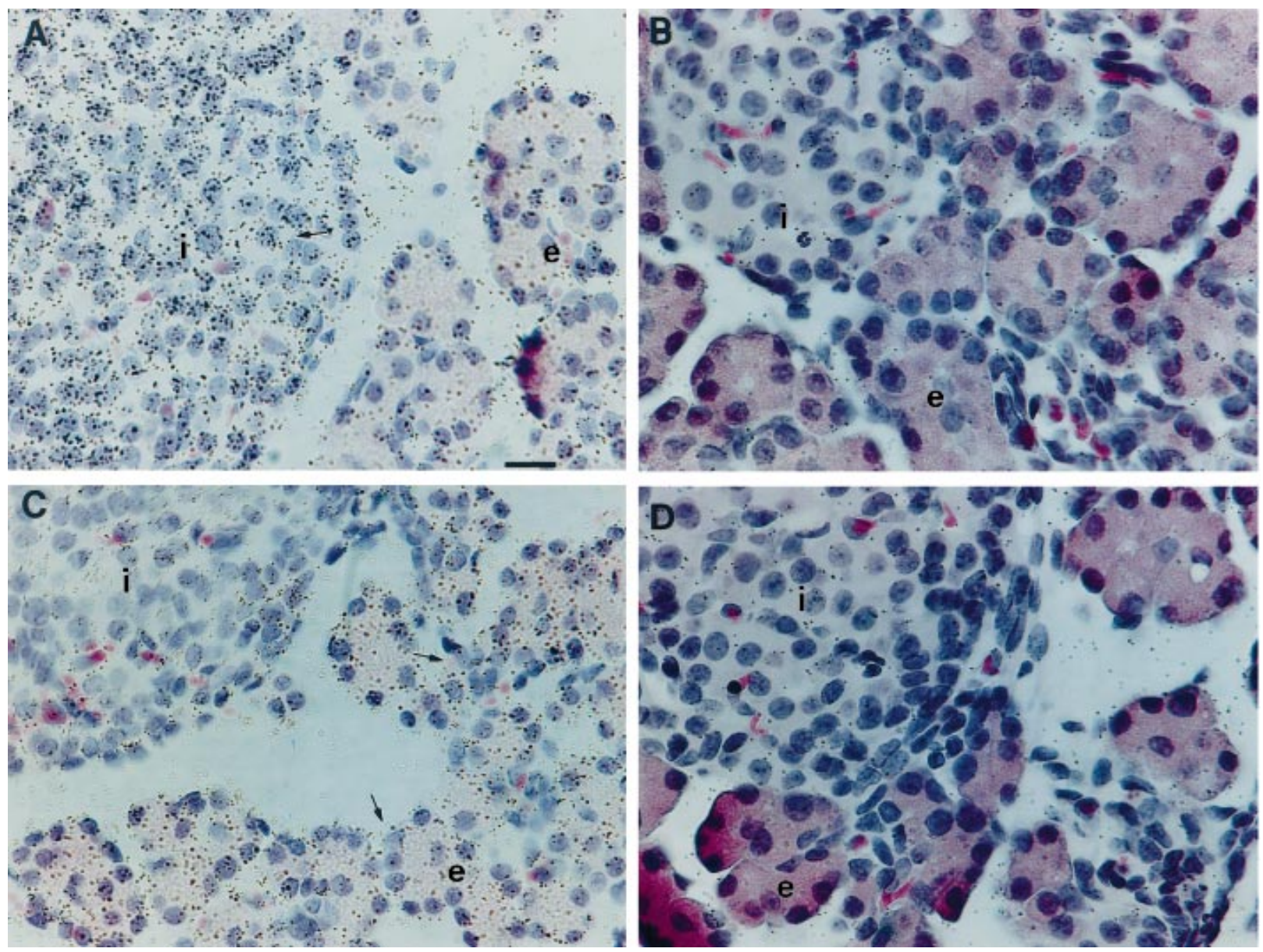

Figure 1 In situ hybridization of IGF-II (A and B) or IGF-I (C and D) mRNAs in tissue sections of rat pancreas from animals of 2 days ( $A$ and $B$ ) or 28 days $(C$ and $D)$ postnatal age. Hybridizations with antisense cRNAs are shown in panels $A$ and $C$, and control hybridizations with sense strand cRNAs are shown in panels B and D. Arrows indicate hybridization signal in the islet cells (i) in A, and in the exocrine tissue (e) in C. Magnification bar $10 \mu \mathrm{m}$.

of different ages, all sections were included in the same hybridization reactions to remove interprocedural variability.

Antisense riboprobes were prepared from cDNAs for rat (r) IGF-I (a gift of Dr L Murphy, University of Manitoba, Canada), mouse (m) IGF-II (a gift of Dr G Bell, University of Chicago, USA), rIGFBPs-1 and -2 (gifts of Dr M M Rechler, NIH, MD, USA); rIGFBP-3 (a gift of Dr A Herington, Queensland University of Technology, Brisbane, Qld, Australia) and rIGFBPs-4, -5 and -6 (gifts of Dr S Shimasaki, University of California, San Diego, CA, USA). The restriction enzymes (BRL, Burlington, ON, Canada) and RNA polymerases (Promega) used to linearize the plasmids containing these cDNAs and to generate $\left[{ }^{35} \mathrm{~S}\right]$ radiolabelled riboprobes are listed as follows: antisense rat IGF-I, HindIII/T7; sense rat IGF-I, PvuII/SP6; antisense mouse IGF-II, HindIII/TSP6; sense mouse IGF-II EcoRI/T7; antisense rIGFBP-1, BamHI/T7; sense rIGFBP-1, AatII/SP6; antisense
rIGFBP-2, HindIII/T7; sense rIGFBP-2, SacI/SP6; antisense rIGFBP-3, HindIII/SP6; sense rIGFBP-3, NdeI/T7; antisense rIGFBP-4, SmaI/T7; sense rIGFBP-4, HindIII/T3; antisense rIGFBP-5, SacII/T7; sense rIGFBP-5, HindIII/T3; antisense rIGFBP-6, SmaI/T7; sense rIGFBP-6, EcoRI/T3. Radiolabelled cRNA probes were synthesised using linearized riboprobe DNA, $\alpha$-thio $\left[{ }^{35} \mathrm{~S}\right] \mathrm{UTP}$, and SP6, T3 or T7 RNA polymerase as described previously (Petrik et al. 1998). To improve cRNA probe penetration of tissue sections, limited alkaline hydrolysis was used to reduce transcript size to about 150 bases.

\section{Morphometric and statistical analysis}

Morphometric analysis was performed using a Zeiss transmitted light microscope at a magnification of $\times 250$. Analyses were performed with Northern Eclipse version 2.0 morphometric analysis software (Empix Imaging Co., 

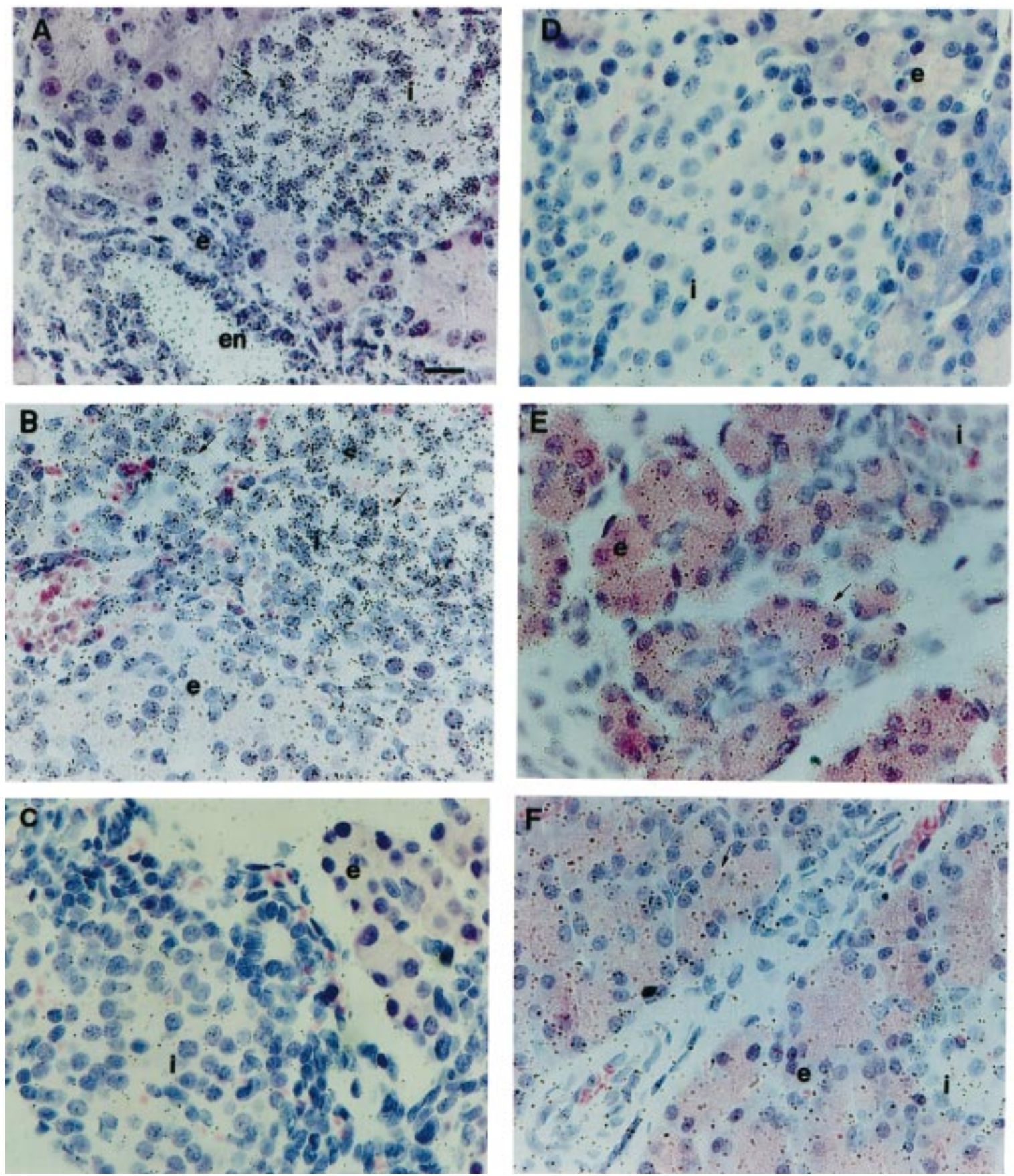

Figure 2 In situ hybridization of IGF-II (A, B and C) or IGF-I (D, E and F) mRNAs in tissue sections of rat pancreas from animals of 19.5 days gestation ( $A$ and $D$ ), 7 days postnatal (B and $E$ ), or 28 days postnatal age (C and F). i, islet; e, exocrine tissue; en, vascular endothelium. Arrows indicate hybridization signal in the islet cells in A and B, and in the acinar tissue in E and F. Magnification bar $10 \mu \mathrm{m}$.

Mississauga, ON, Canada). The percentage of islet cells immunopositive for IGF-I, IGF-II or IGFBPs-1 to -6 was calculated at each age from five sections of each pancreas representing both head and tail regions. Sections chosen contained at least five islets, and pancreata from at least five animals were examined for each age. 

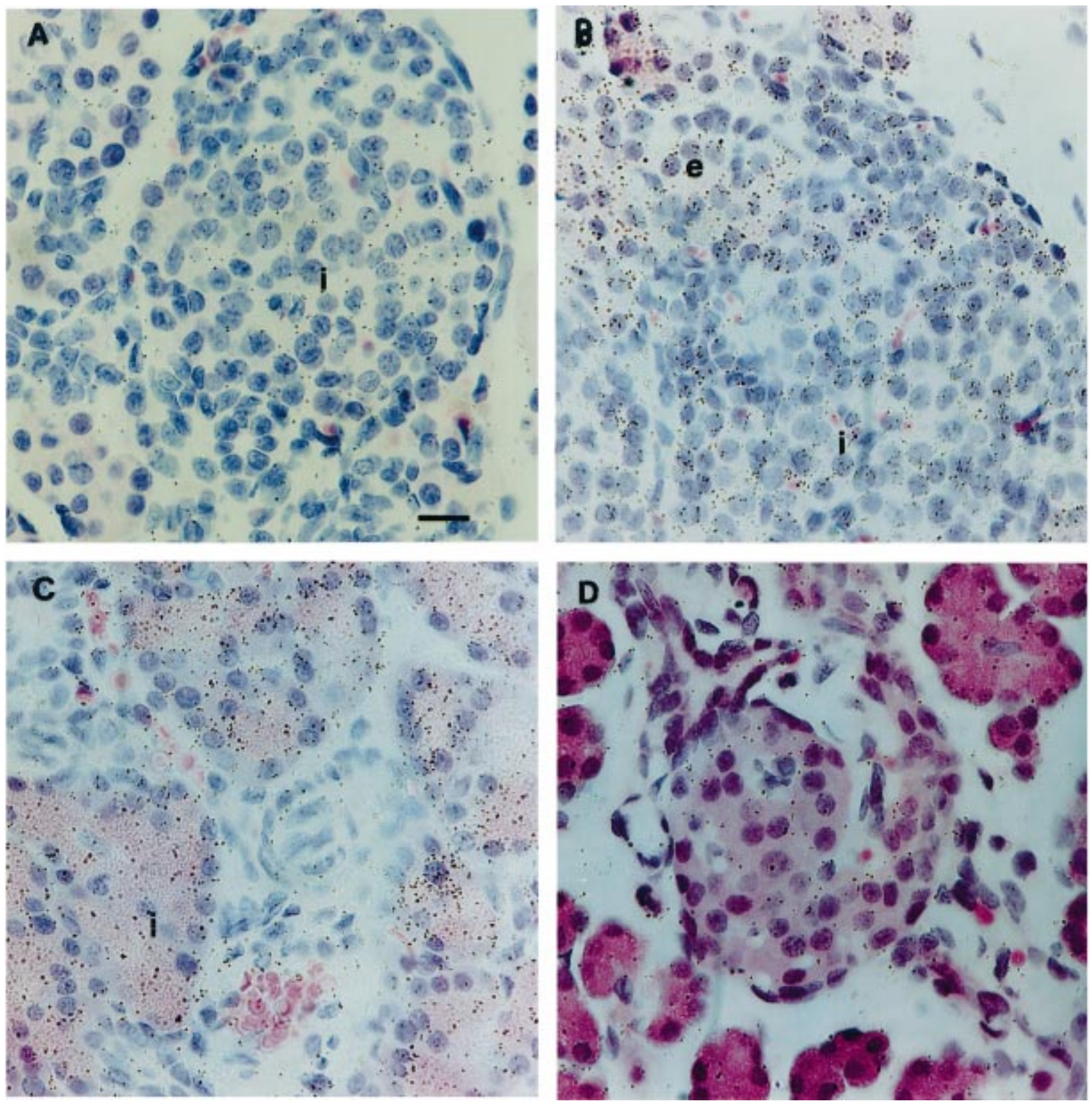

Figure 3 In situ hybridization to visualize IGFBP-2 mRNA (A, B and C) in tissue sections of rat pancreas from animals of 7 (A), 14 (B), or 28 (C) days postnatal age. Control hybridization with a sense strand cRNA is shown in panel D. i, islet; e, exocrine tissue. Magnification bar $10 \mu \mathrm{m}$.

\section{Results}

IGF-II mRNA was identified in high abundance in the pancreatic islets, and in low abundance in the acinar and ductal tissues of the two-day postnatal rat pancreas (Fig. 1A). Hybridization with a sense IGF-II probe (Fig. 1B), or incubation of tissue sections with RNase prior to hybridization with an antisense IGF-II probe (not shown), resulted in no hybridization signal. IGF-I mRNA was detected in the acinar and ductal cells of the pancreas at 28 days postnatal life (Fig. 1C). The hybridization signal was not widespread within the islets of Langerhans, but was greater in cells on the outer edge of the islets. No hybridization signal was seen when a sense strand cRNA for IGF-I was used (Fig. 1D) or when the sections were pre-treated with RNase. This demonstrated that 

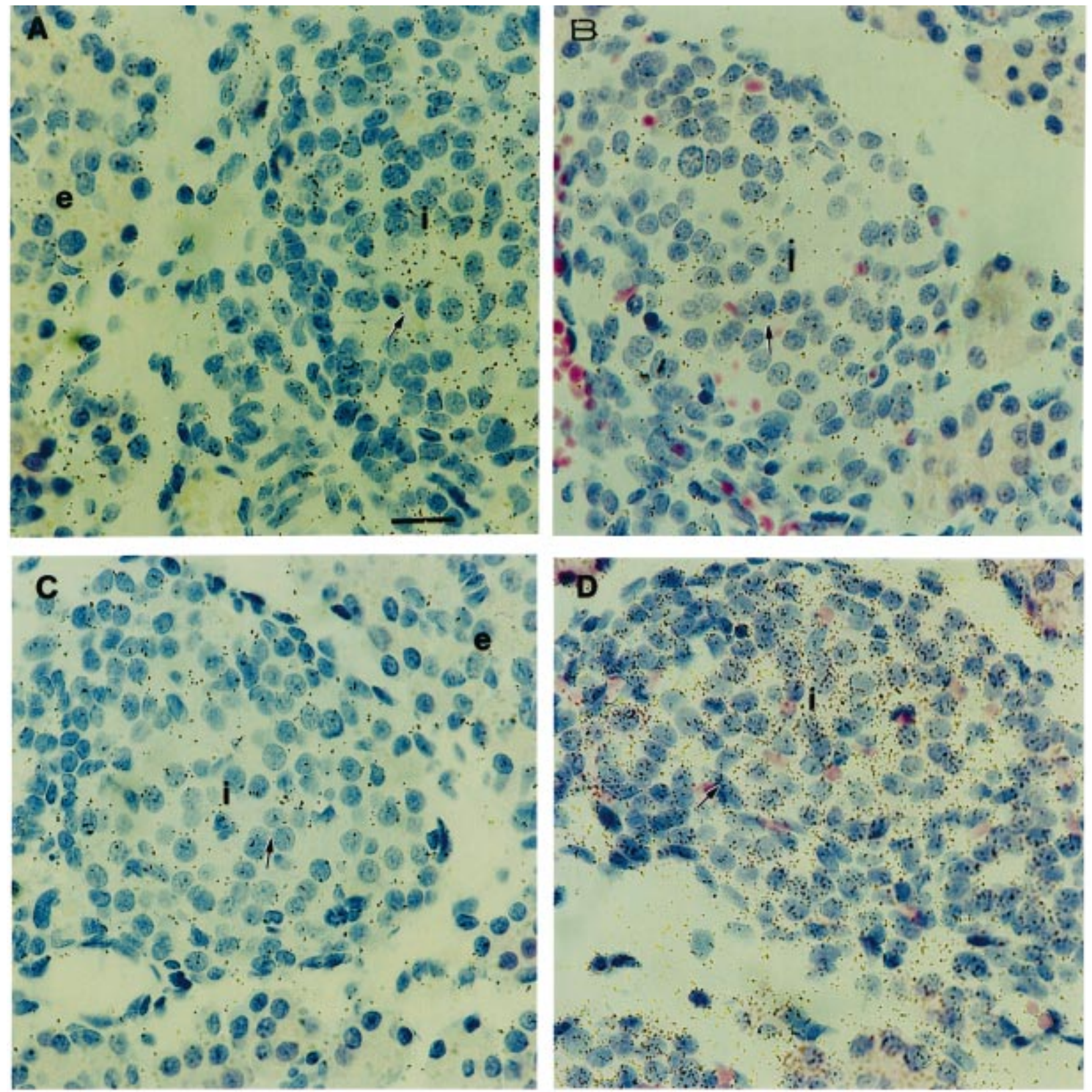

Figure 4 In situ hybridization of mRNAs encoding IGFBP-1 (A), IGFBP-3 (B), IGFBP-4 (C) or IGFBP-5 (D) in tissue sections of rat pancreas from animals of 14 days postnatal age. i, islet; e, exocrine tissue. Arrows indicate hybridization signal in the islet cells. Magnification bar $10 \mu \mathrm{m}$.

both IGFs-I and -II mRNAs were identified within specific compartments of the rat pancreas and that the hybridization was specific.

Comparison of sections of pancreata taken at differing ages showed clear ontological patterns of IGF expression in pancreas. In pancreata taken between $19 \cdot 5$ days fetal life and 7 days postnatal life, IGF-II mRNA was abundant in the islets of Langerhans (Fig. 2A,B). IGF-II hybridization signal was also associated with ductal epithelial cells and some acinar cells. At postnatal days 17, 21 and 28, a much reduced IGF-II expression was seen in islets, with little signal remaining in acinar and ductal tissue (Fig. 2C). At postnatal days 10-14, an intermediate hybridization intensity was seen. Conversely, little or no hybridization for IGF-I mRNA was seen in fetal and neonatal pancreas in either islet or acinar cells (Fig. 2D). In pancreas at postnatal 
Table 1 Semi-quantitative assessment of the abundance of IGFBP mRNAs within cellular compartments of the rat pancreas with age

\begin{tabular}{|c|c|c|c|c|c|c|c|}
\hline & \multicolumn{7}{|c|}{ Age (days) } \\
\hline & F19.5 & F21.5 & P2 & P7 & P14 & P21 & P28 \\
\hline \multicolumn{8}{|l|}{ IGFBP-1 } \\
\hline Islet & - & - & - & - & + & ++ & ++ \\
\hline Acinar & - & - & - & - & - & - & - \\
\hline \multicolumn{8}{|l|}{ IGFBP-2 } \\
\hline Islet & - & - & - & - & + & ++ & + \\
\hline Acinar & - & - & - & + & ++ & +++ & ++ \\
\hline \multicolumn{8}{|c|}{ IGFBP-3, -4 } \\
\hline Islet & + & + & + & + & + & + & + \\
\hline Acinar & - & - & - & - & - & - & - \\
\hline \multicolumn{8}{|l|}{ IGFBP-5 } \\
\hline Islet & + & + & + & + & + & + & + \\
\hline Acinar & + & + & + & + & + & + & + \\
\hline
\end{tabular}

F, fetal age; P, postnatal age; - , No mRMA detectable;,,++++++ , increasing abundance of mRNA hybridization signal.

day 7, IGF-I mRNA hybridization was now seen in ductal and acinar cells, with a low level of hybridization in islet cells (Fig. 2E), and this was maintained up to postnatal day 28 (Fig. 2F). Therefore, we have observed a relatively high expression of IGF-II mRNA within islets in late fetal and neonatal life which decreased between one and two weeks following birth, and was almost absent by weaning. IGF-I mRNA expression was low in all cell compartments of the pancreas in early life, but appeared in acinar tissue and in some islet cells by weaning.

IGFBP-2 mRNA was of low abundance in islets and absent from acinar tissue at fetal ages and up to postnatal day 7 (Fig. 3A). At postnatal days 14 and 21, the mRNA was more abundant in acinar tissue and in the outer cell mantle of islets (Fig. 3B), and became less prominent at postnatal day 28 (Fig. 3C). IGFBP-1 mRNA was also of low abundance in the pancreas prior to postnatal day 7 . At postnatal days 14 to 28 , IGFBP-1 mRNA was located evenly within cells of the islets (Fig. 4A). IGFBPs-3 and -4 mRNAs were located throughout the islets and did not obviously change in abundance with age (Fig. 4B,C). IGFBP-5 mRNA was seen at all ages and in all regions of the islet, although the signal intensity was greatest in the outer mantle of predominantly $\alpha$ cells (Fig. 4D). IGFBP-5 was also expressed in the acinar cells. No difference in hybridization signal for IGFBP-6 was seen at any age with antisense probe compared with sense control, suggesting a low level of abundance for this mRNA. A semiquantitative assessment of the changes in IGFBP mRNA expression with age in pancreas is shown in Table 1.

Immunohistochemistry for IGF-II showed strong staining of the fetal and neonatal islets and occasional ductal epithelial cells up to postnatal day 2 (Fig. 5A). Within the islets, the staining was most apparent in the central, $\beta$ cell-rich core, whereas the periphery of the islets was immunonegative. The staining was abolished by pre-incubation of the primary antiserum with excess IGF-II (Fig. 5B), demonstrating that this was specific and unlikely to represent cross-reactivity with insulin. The distribution of IGF-II peptide differed from that of the IGF-II mRNA, which was present in all regions of the islets. By postnatal day 10, staining for IGF-II immunoreactivity in the islets was less uniform (Fig. 5C) and by day 21 it was barely detectable (Fig. 5D). The change in the area of islets immunopositive for IGF-II with age is shown in Fig. 6. Immunoreactivity for IGF-I in pancreas was low in the fetus, but steadily increased with postnatal age (Fig. 6). At older ages, a diffuse staining was seen in many cells of the islets, and in the acinar cell lobules (Fig. 7A). Again, a discrepancy existed beween the presence of some IGF-I immunoreactivity in fetal and neonatal islets and a lack of mRNA for IGF-I. Immunoreactive IGFBP-1 was diffusely present in islet cells in the fetus, and the area of immunopositve cells declined with age (Fig. 6). IGFBP-1 was also present in certain acinar and mesenchymal cells at all ages, but staining was most intense at postnatal day 21 (Fig. 7B). IGFBP-2 immunoreactivity was predominantly associated with the outer mantle of islet cells, comprised mostly of $\alpha$ cells, and vascular endothelium. The extent of islet cell IGFBP-2 immunoreactivity did not change greatly with age (Figs 6 and 7C). IGFBP-3 immunoreactivity was seen at all ages within the pancreas, in both islets and mesenchymal tissues, but not in most acinar cells (Fig. 7D). Many islet 

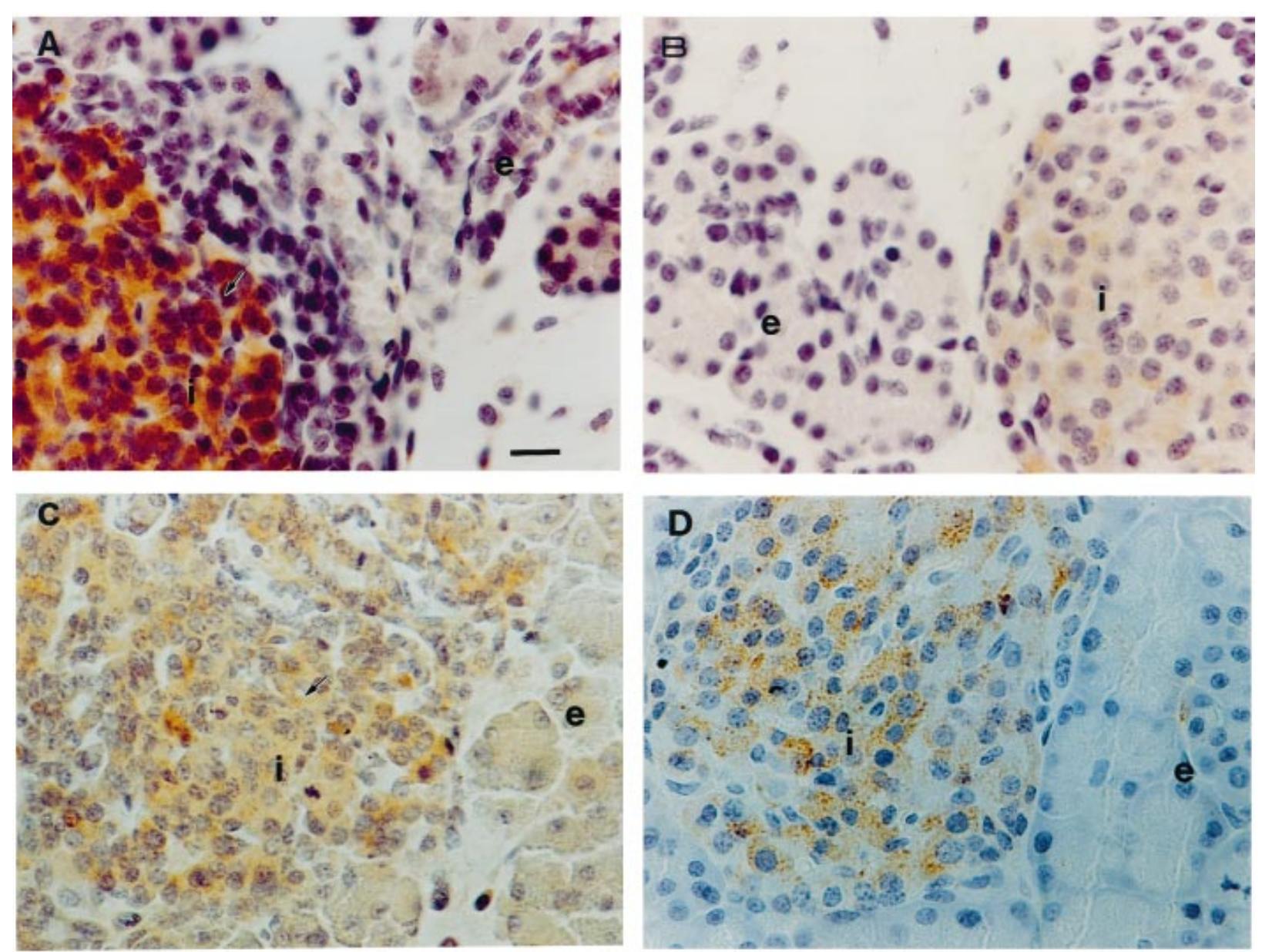

Figure 5 Immunohistochemistry of IGF-II in sections of rat pancreas from animals of 2 (A), 10 (C), or 21 (D) days postnatal age. The absence of staining observed when the primary antiserum was pre-absorbed with excess IGF-II is shown in panel B. i, islets; e, exocrine tissue. Arrows indicate immunoreactivity associated with islet cells. Magnification bar $10 \mu \mathrm{m}$.

cells showed a pronounced nuclear localization of IGFBP-3, and the proportion of islet cells immunopositive for IGFBP-3 increased with postnatal age (Fig. 6). IGFBP-3 immunoreactivity was greater in the outer cells of the islets. IGFBP-4 was similarly distributed, but showed no nuclear localization. Immunoreactivity for IGFBP-5 was also seen at all ages and was identified in the $\alpha$ cells of the islets and with ductal epithelial cells (Fig. 7E).

\section{Discussion}

These findings demonstrate that the developing rat pancreas has a dynamic and differential expression of IGFs and their binding proteins. As in most fetal and neonatal rat tissues (Brown et al. 1986, Lund et al. 1986), the expression of IGF-II mRNA in pancreas, as detected by in situ hybridization, is much higher than that of IGF-I, which was virtually undetectable in any cell type prior to postnatal day 7. This agrees with our previous report that IGF-I mRNA was very low when assessed by Northern blot hybridization of total RNA from whole pancreata (Hogg et al. 1994). In the fetus and neonate, IGF-II mRNA is largely associated with pancreatic endocrine cells, but was not restricted to any single islet cell type, since the hybridization signal was seen in both the inner zone of the islets, which is rich in $\beta$ cells, and the outer mantle, which has an abundance of $\alpha$ cells. IGF-II immunoreactivity showed a similar distribution, but was more intense in the inner core than the outer mantle of the islets. It is possible that this distribution is dictated by islet-associated IGFBPs, but at least three of these, IGFBPs $-2,-3$ and -5 are more clearly associated with the $\alpha$ cells than the central $\beta$ cells. Alternatively, IGF-II peptide distribution could be determined, in part, by binding to the type II IGF/mannose 6-phosphate receptor which is abundant on $\beta$ cells (Fehmann et al. 1996, Ishiwata et al. 1997). 


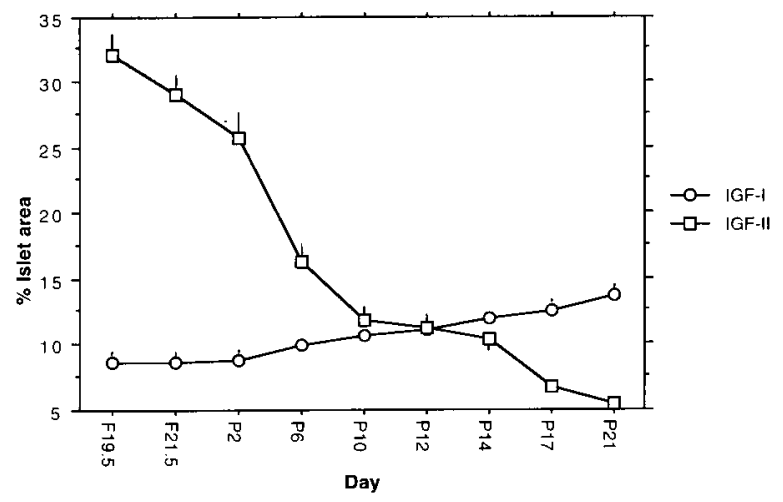

B

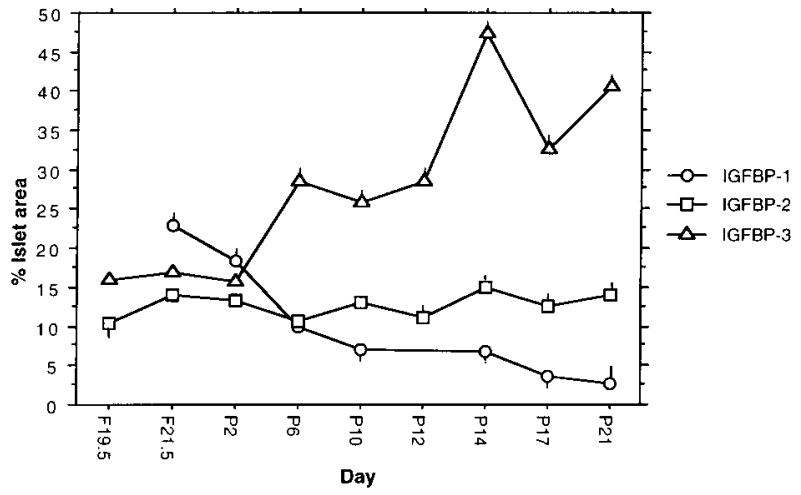

C

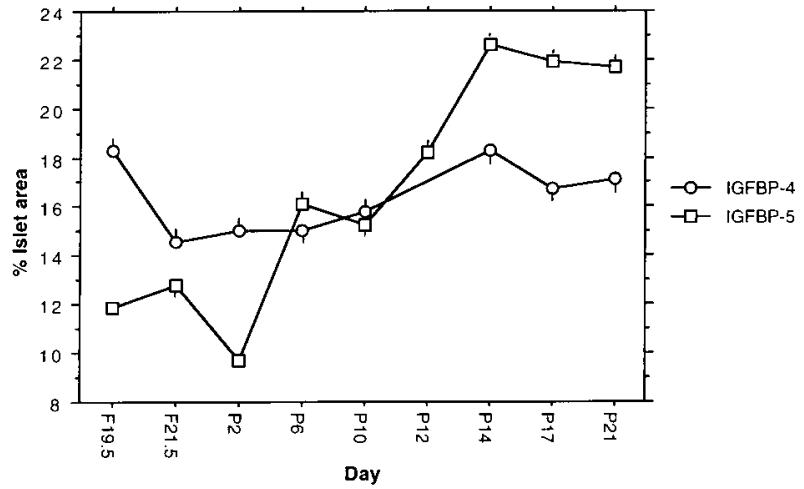

Figure 6 Percentage area of islets immunopositive for IGF-I and IGF-II (A), IGFBPs-1, -2 and -3 (B), or IGFBPs-4 and -5 (C) in rats from $19 \cdot 5$ days gestation $(\mathrm{F})$ to 21 days postnatal $(\mathrm{P})$ age. Panels show the mean values ( \pm S.D.) for at least five sections from each of five pancreata at each age.

IGF-II synthesis is a common feature of isolated rodent and human islets derived in fetal or neonatal life (Rabinovitch et al. 1982, Bryson et al. 1989, Hogg et al. 1993), and from $\beta$ cell lines which maintain a fetal-like, proliferative phenotype (Asfari et al. 1995). The role of
IGF-II in the pancreas of the fetus and neonate is likely to be that of a paracrine or autocrine mitogen. Recently, we reported that an IGF-II transgenic mouse model exhibited fetal overgrowth with increased pancreatic weight and a five-fold increase in islet cell mass (Hill et al. 1998). Islets were bigger with an increased complement of $\beta$ cells, but islet number was unaltered, suggesting that IGF-II did not act as an islet neogenic factor, but served as a growth factor for existing islets.

We have shown previously that IGF-II mRNA levels decrease in the pancreas between 14 and 21 days after birth (Hogg et al. 1994), to become undetectable. The present study shows that this represents specifically a loss of expression from pancreatic islet cells. The timing of the loss of expression of IGF-II in pancreatic islets corresponds to a wave of developmental $\beta$ cell apoptosis (Scaglia et al. 1997), and we have demonstrated that IGF-II functions as a survival factor for isolated islets from the neonatal rat which will prevent the induction of $\beta$ cell apoptosis by cytokines (Petrik et al. 1998). A fall in IGF-II expression within neonatal islets may, therefore, be functionally linked to developmental $\beta$ cell apoptosis, and the replacement of these cells through islet cell neogenesis from pancreatic ductal epithelial cells. The mechanism by which the IGF-II expression in islets is lost during neonatal life is not known, but could be linked to altered nutrition, or a maturation of the immune system and the colonization of the pancreas with macrophages and dendritic cells at this time (Grove et al. 1991). The fall in IGF-II expression in pancreas may also be linked to changes in the ontogeny of glucocorticoids and the glucocorticoid receptor at this time. Corticosterone levels rise appreciably in the rat circulation between two and three weeks of postnatal life at a time when glucocorticoid receptors appear in the pancreas (Lu et al. 1987, Matthes et al. 1994), to be found mainly on $\beta$ cells in the adult (Fischer et al. 1990). In the fetal sheep, a sharp decrease in the expression of IGF-II prior to birth, at least in the liver, has been shown to be functionally linked to a rise in circulating cortisol ( $\mathrm{Li}$ et al. 1998). In the hyperinsulinaemic Goto-Kakizaki (GK) rat, which develops a noninsulin-dependent diabetes, inappropriately processed IGF-II of high molecular weight continues to be synthesized by large, irregular shaped islets at 2-3 months of age (Hoog et al. 1996). Immunoreactive IGF-II was localized, together with insulin, to secretory granules in a sub-set of islet $\beta$ cells in the GK rat (Hoog et al. 1997). In situations of $\beta$ cell hyperplasia, therefore, a prolonged expression of IGF-II may occur in the pancreas.

IGF-I mRNA was absent from the fetal and neonatal pancreas, but appeared by postnatal day 7 , predominantly in exocrine tissue and with a low abundance in islets. Acinar tissue contains type-1 and type-2 IGF receptors, and insulin receptors (Mossner et al. 1984), the type 1 receptors mediating weak mitogenic actions of IGFs and an activation of phospholipase D (Rydzewska \& Morisset 

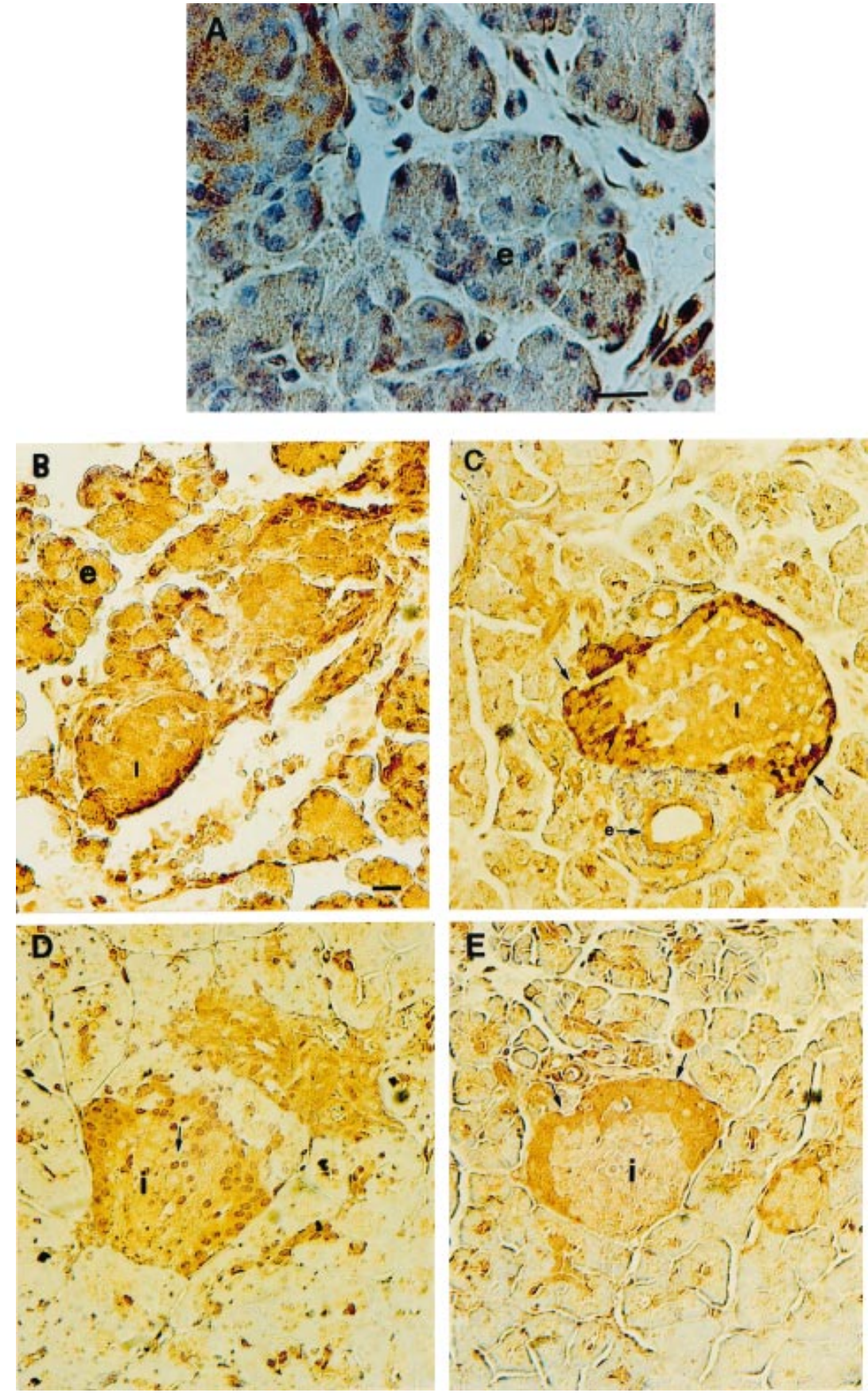

Figure 7 Immunohistochemistry of IGF-I (A), IGFBP-1 (B), IGFBP-2 (C), IGFBP-3 (D) or IGFBP-5 (E) in sections of rat pancreas from animals of 21 days postnatal age. i, islets; e, exocrine tissue. Arrows indicate immunoreactivity associated with islet cells. Magnification bar $10 \mu \mathrm{m}$.

1995). The ontogeny of IGF-I gene expression in acinar tissue may relate to the maturation of the growth hormone receptor, and the onset of growth hormone-dependent IGF-I expression (Mathews et al. 1986). Isolated islets from the 20-22 day gestation rat fetus release insulin and demonstrate increased DNA synthesis in response to GH, the latter mediated partly by a release of IGF-I (Swenne et al. 1987). However, such cultures are maintained in vitro 
for 7-10 days prior to experimentation, suggesting that the timing of onset of growth hormone-dependent IGF-I expression is maintained ex vivo. A contribution of pancreatic IGF-I expression to the proliferation of both exocrine and endocrine tissue is supported by an increased IGF-I synthesis during the compensatory islet hyperplasia and acinar regrowth which follows sub-total pancreatectomy in the young rat or dog (Hayakawa et al. 1996, Calvo et al. 1997). In the regenerating rat pancreas, IGF-I mRNA was localized to epithelial cells of proliferating ductules, the source of new islets by a process of neogenesis, and to endothelial cells of the supporting vasculature (Smith et al. 1991). In the present study, immunoreactive IGF-I was seen at low abundance in islet cells in fetal and early neonatal life, but it increased in intensity with age. IGF-I was also located in a subpopulation of acinar and ductal cells. This is in agreement with a localization of IGF-I to $\alpha, \beta$ and somatostatin cells in adult rat islets of Langerhans, although a localization to somatostatin cells was reported to be strongest (Hansson et al. 1988). The localization of IGF-I to islet cells despite very low levels of mRNA suggests a sequestration of endocrine IGF-I at the cell surface by IGFBPs as a likely explanation.

At least six IGFBP molecules are capable of binding IGFs-I or -II, of which IGFBPs-1 to -4 have previously been shown to be released from isolated fetal rat islets after one week of culture (Hogg et al. 1993). We have previously shown separate ontological patterns of expression of IGFBPs-1 to -4 mRNAs in fetal and neonatal rat pancreas by Northern blot hybridization (Hogg et al. 1994), IGFBPs-1 and -2 mRNAs appearing after postnatal day 7 and being maximal by day 21 , while IGFBPs-3 and -4 mRNAs were present throughout late fetal and neonatal life with greatest abundance 7-14 days after birth. The present study provides further evidence that IGFBPs-1 to -5 mRNAs are all present within fetal and/or neonatal islets with discrete expression patterns. IGFBP-2 mRNA appeared after postnatal day 7 and was predominantly localized to the outer mantle of $\alpha$ cells, as was the immunoreactive peptide. IGFBP-5 mRNA and peptide and IGFBP-3 also predominated in the outer zones of the islets, but were present from late fetal life. IGFBP-1 mRNA did not appear until around postnatal day 14, although peptide immunoreactivity associated with islets was much greater at earlier ages. This suggests that, in late fetal and early neonatal life, the source of islet-associated IGFBP-1 is from the circulation.

The cellular distributions of IGFBPs suggest functional contributions to IGF action in islet cell growth and function. We previously showed that exogenous IGFBPs- 1 and -2 could potentiate the mitogenic actions of IGF-II on isolated, $\beta$ cell-enriched fetal rat islets (Hogg et al. 1993), while IGFBP-3 inhibited IGF-II action (D J Hill, unpublished observation). The expression of human
IGFBP-1 in transgenic mice caused a hyperplasia of pancreatic islet cells, leading to increased $\beta$ cell mass (Rajkumar et al. 1996). Islets isolated from these animals showed an increased release of insulin in response to glucose (Dheen et al. 1996), demonstrating a functional role for IGFBP-1 in islet cell growth and function. Since IGFBPs-2 and -3 peptides are predominantly associated with the outer, $\alpha$ cell-rich area of the islets, a contribution to $\beta$ cell growth is likely to represent a paracrine rather than an autocrine interaction. In contrast, since IGFBP-1 is not expressed locally within the pancreas to any extent prior to postnatal day 14, any influence on islet cell development must be from the circulating IGFBP-1 derived almost exclusively from the liver in early life (Lund et al. 1986). A fall in endogenous expression of islet IGF-II after postnatal day 7 is associated with the onset of $\beta$ cell apoptosis (Petrik et al. 1998). A substantial increase in the localization of IGFBP-3 to islet cells at this time may limit IGF-II availability, and potentiate the onset of apoptosis. The IGF axis within islets could also contribute to the endocrine function of non- $\beta$ cell types, since IGF-I potently inhibited proglucagon gene expression and glucagon release from a glucagon-secreting islet cell line, while potentiating somatostatin release from RIN 1027B2 cells (Fehmann et al. 1996). The association of IGFBPs-2, -3 and -5 with the $\alpha$ cell-rich area of the outer islet would implicate them in the modulation of IGF action in glucagon and somatostatin release, although no direct functional evidence exists as yet. Of the IGFBPs studied, only IGFBP-3 demonstrated a nuclear localization within islet cells. This has been observed for other cell types (Jaques et al. 1997, Li et al. 1997), and in kidney cells it has been associated with a transport of IGF-I to the nucleus (Li et al. 1997). In the pancreas we did not detect any nuclear association of immunoreactive IGFs-I or -II in islet cells, suggesting that any biological functions of nuclear IGFBP-3 are independent of an IGF transport role.

Islet neogenesis from pancreatic ductal epithelial cells is ongoing in the fetus and neonate, and a wave of neogenesis two to three weeks after birth in the rat replaces $\beta$ cells lost at this time by apoptosis (Finegood et al. 1995). We found a substantial localization of IGFBPs-1, -2 and -5 to sub-population of ductal and acinar cells, with IGFBP-2 especially increasing in its presence after postnatal day 7 . Since both IGF-II in the fetus, and IGF-I in the neonate, are expressed and localized to similar cells, and IGF-I expression is increased during neonatal pancreas regeneration (Smith et al. 1991), it seems likely that interactions of IGFs with IGFBPs also modulate the expansion of new endocrine cell populations.

In summary, these experiments show a dynamic and regional distribution of IGF and IGFBP mRNA expression and peptide immunoreactivity within the developing rat pancreas, which would support an important role for the IGF axis in endocrine pancreatic 
maturation, and the determination of $\beta$ cell mass and insulin availability.

\section{Acknowledgements}

We are grateful to the Juvenile Diabetes Foundation, the Canadian Diabetes Association and the Medical Research Council of Canada for financial support.

\section{References}

Asfari M, Wei D, Noel M, Holthuizen PE \& Czernichow P 1995 IGF-II gene expression in a rat insulin-producing $\beta$-cell line (INS-1) is regulated by glucose. Diabetologia 38 927-935.

Brown AL, Graham DE, Nissley SP, Hill DJ, Strain AJ \& Rechler MM 1986 Developmental regulation of insulin-like growth factor-II mRNA in different rat tissues. Journal of Biological Chemistry 261 13144-13150.

Bryson JM, Tuch BE \& Baxter RC 1989 Production of insulin-like growth factor-II by human fetal pancreas in culture. Journal of Endocrinology 121 367-373.

Calvo EL, Bernatchez G, Pelletier G, Iovanna JL \& Morisset J 1997 Downregulation of IGF-I mRNA expression during postnatal pancreatic development and overexpression after subtotal pancreatectomy and acute pancreatitis in the rat pancreas. Journal of Molecular Endocrinology 18 233-242.

Dheen ST, Rajkumar K \& Murphy LJ 1996 Effects of insulin-like growth factors (IGF) on pancreatic islet function in IGF binding protein-1 transgenic mice. Diabetologia 11 1249-1254.

Fehmann HC, Jehle P, Markus U \& Gobe B 1996 Functional active receptors for insulin-like growth factors-I (IGF-I) and IGF-II on insulin-, glucagon-, and somatostatin-producing cells. Metabolism $\mathbf{4 5}$ $759-766$.

Finegood DT, Scaglia L \& Bonner-Weir S 1995 Dynamics of $\beta$ cell mass in the growing rat pancreas. Diabetes 44 249-256.

Fischer B, Rausch U, Wollny P, Westphal H, Seitz J \& Aumuller G 1990 Immunohistochemical localization of the glucocorticoid receptor in pancreatic $\beta$ cells of the rat. Endocrinology 126 2635-2641.

Grove DS, Bour B, Kacsoh B \& Mastro AM 1991 Effect of neonatal milk-protein deprivation on the ontogeny of the immune system in the rat. Endocrine Regulation 25 111-119.

Guler H-P, Schmid C, Zapf J \& Froesch ER 1989 Effects of recombinant insulin-like growth factor-I on insulin secretion and renal function in normal human subjects. Proceedings of the National Academy of Sciences of the USA 86 2868-2872.

Hansson HA, Edwall D, Lowenadler B, Norstedt G, Paleus S \& Skottner A 1988 Insulin-like growth factor-I in the pancreas of normal and diabetic rats. Acta Physiologica Scandinavica 132 569-576.

Hayakawa H, Kawarada Y, Mizumoto R, Hibasami H, Tanaka M \& Nakashima K 1996 Induction and involvement of endogenous IGF-I in pancreas regeneration after partial pancreatectomy in the dog. Journal of Endocrinology 149 259-267.

Hill DJ \& Clemmons DR 1992 Similar distribution of insulin-like growth factor binding proteins-1, -2 and -3 in human fetal tissues. Growth Factors 6 315-326.

Hill DJ, Frazer A, Swenne I, Wirdnam PK \& Milner RDG 1987 Somatomedin-C in the human fetal pancreas: cellular localization and release during organ culture. Diabetes 36 465-471.

Hill DJ, Sedran RJ, Brenner SL \& McDonald TJ 1997 Insulin-like growth factor-I (IGF-I) has a dual effect on insulin release from isolated, perifused adult rat islets of Langerhans. Journal of Endocrinology 153 15-25.
Hill DJ, Petrik J, Arany E, Reik W \& Pell JM 1998 Insulin-like growth factors in the development of the pancreas. In Molecular Mechanisms to Regulate the Activities of Insulin-Like Growth Factors, pp 145-153. Eds K Takano, N Hizuka \& S-I Takahashi. Amsterdam: Elsevier Science.

Hogg J, Han VKM, Clemmons DR \& Hill DJ 1993 Interactions of glucose, insulin-like growth factors (IGFs) and IGF binding proteins in the regulation of DNA synthesis by isolated fetal rat islets of Langerhans. Journal of Endocrinology 138 401-412.

Hogg J, Hill DJ \& Han VKM 1994 The ontogeny of insulin-like growth factor (IGF) and IGF binding protein gene expression in the rat pancreas. Journal of Molecular Endocrinology 13 49-58.

Hoog A, Sandberg Nordqvist AC, Abdel Halim SM, Carlsson Akwirut C, Guenifi A, Tally M et al. 1996 Increased amounts of a high molecular weight insulin-like growth factor-II (IGF-II) peptide and IGF-II messenger ribonucleic acid in pancreatic islets of diabetic Goto-Kakizaki rats. Endocrinology 137 2415-2423.

Hoog A, Hu W, Abdel Halim SM, Falkmer S, Qing L \& Grimelius L 1997 Ultrastructural localization of insulin-like growth factor-2 (IGF-2) to the secretory granules of insulin cells: a study in normal and diabetic (GK) rats. Ultrastructural Pathology 21 457-466.

Hsu SM, Raine L \& Fanger H 1981 Use of avidin-biotin peroxidase complex $(\mathrm{ABC})$ in immunoperoxidase techniques: a comparison between $\mathrm{ABC}$ and unlabelled antibody (PAP) procedures. Journal of Histochemistry and Cytochemistry 29 577-580.

Ishiwata T, Bergmann U, Kornmann M, Lopez M, Beger HG \& Korc M 1997 Altered expression of insulin-like growth factor-II receptor in human pancreatic cancer. Pancreas 15 367-373.

Jaques G, Noll K, Wegmann B, Witten S, Kogan E, Radulescu RT \& Havemann K 1997 Nuclear localization of insulin-like growth factor binding protein-3 in a lung cancer cell line. Endocrinology 138 1767-1770.

Li W, Fawcett J, Widmer HR, Fielder PJ, Rabkin R \& Keller GA 1997 Nuclear transport of insulin-like growth factor-I and insulinlike growth factor binding protein-3 in opossum kidney cells. Endocrinology 138 1763-1766.

Li J, Saunders JC, Fowden AL, Dauncey MJ \& Gilmour RS 1998 Transcriptional regulation of insulin-like growth factor-II gene expression by cortisol in fetal sheep during late gestation. Journal of Biological Chemistry 273 10586-10593.

Lu RB, Lebenthal E \& Lee PC 1987 Developmental changes of glucocorticoid receptors in rat pancreas. Journal of Steroid Biochemistry 26 213-218.

Lund PK, Moats-Staats BM, Hynes MA, Simmons JG, Jansen M, D’Ercole AJ \& Van Wyk JJ 1986 Somatomedin-C/insulin-like growth factor-I and insulin-like growth factor-II mRNAs in rat fetal and adult tissues. Journal of Biological Chemistry 261 14539-14544.

McCusker RH \& Clemmons DR 1992 The insulin-like growth factor binding proteins: structure and biological functions. In The InsulinLike Growth Factors, Structure and Biological Functions, pp 110-150. Ed PN Schofield. Oxford: Oxford University Press.

Mathews LS, Norstedt G \& Palmiter RD 1986 Regulation of insulin-like growth factor-I gene expression by growth hormone. Proceedings of the National Academy of Sciences of the USA 83 9343-9347.

Matthes H, Kaiser A, Stier U, Riecken EO \& Rosewicz S 1994 Glucocorticoid receptor gene expression in the exocrine and endocrine rat pancreas. Endocrinology 135 476-479.

Mossner J, Logsdon CD, Potau N, Williams JA \& Goldfine ID 1984 Effect of intracellular $\mathrm{Ca}^{2+}$ on insulin-like growth factor-II internalization into pancreatic acini. Roles of insulin and cholecystokinin. Journal of Biological Chemistry 259 12350-12356.

Petrik J, Arany E, McDonald TJ \& Hill DJ 1998 Apoptosis in the pancreatic islet cells of the neonatal rat is associated with a reduced expression of insulin-like growth factor-II that may act as a survival factor. Endocrinology 139 2994-3004. 
Rabinovitch A, Quigley C, Russel T, Patel Y \& Mintz DH 1982 Insulin and multiplication stimulating activity (an insulin-like growth factor) stimulate islet $\beta$-cell replication in neonatal rat pancreatic monolayer cultures. Diabetes $\mathbf{3 1}$ $160-164$

Rajkumar K, Dheen ST \& Murphy LJ 1996 Hyperglycemia and impaired glucose tolerance in IGF binding protein-1 transgenic mice. American Journal of Physiology 270 E565-E571.

Romanus JA, Rabinovitch A \& Rechler MM 1985 Neonatal rat islet cell cultures synthesize insulin-like growth factor-I. Diabetes 34 696-702.

Rydzewska G \& Morisset J 1995 Activation of pancreatic acinar cell phospholipase D by epidermal, insulin-like, and fibroblast growth factors involves tyrosine kinase. Pancreas 10 59-65.

Scaglia L, Cahill CJ, Finegood DT \& Bonner-Weir S 1997 Apoptosis participates in the remodeling of the endocrine pancreas in the neonatal rat. Endocrinology 138 1736-1741.

Scharfmann R, Corvol M \& Czernichow P 1989 Characterization of IGF-I produced by fetal rat pancreatic cells. Diabetes $\mathbf{3 8}$ 686-690.
Smith FE, Rosen KM, Villa-Komaroff L, Weir GC \& Bonner-Weir S 1991 Enhanced insulin-like growth factor-I gene expression in regenerating rat pancreas. Proceedings of the National Academy of Sciences of the USA 88 6152-6156.

Swenne I, Hill DJ, Strain AJ \& Milner RDG 1987 Growth hormone regulation of somatomedin-C/insulin-like growth factor-I production and DNA replication in fetal rat islets in tissue culture. Diabetes 36 288-294.

Van Schravendijk CF, Foriers A, Van Den Brande JL \& Pipeleers DG 1987 Evidence for the presence of type I insulin-like growth factor receptors on rat pancreatic A and B cells. Endocrinology 121 1784-1788.

Van Schravendijk CFH, Heylen L, Van Den Brande JL \& Pipeleers DG 1990 Direct effect of insulin and insulin-like growth factor-I on the secretory activity of rat pancreatic beta cells. Diabetologia $\mathbf{3 3}$ 649-653.

Received 14 July 1998

Accepted 8 October 1998 